\title{
An Overview of Kenyan Aquaculture: Current Status, Challenges, and Opportunities for Future Development
}

\author{
Jonathan Mbonge Munguti ${ }^{1 *}$, Jeong-Dae $\mathrm{Kim}^{2}$ and Erick Ochieng Ogello ${ }^{3}$ \\ ${ }^{1}$ Kenya Marine \& Fisheries Research Institute (KMFRI), National Aquaculture Research Development \& Training Center \\ (NARDTC) Sagana, P.O. Box 26, Sagana, Kenya \\ ${ }^{2}$ Department of Animal Life System, College of Animal Life Sciences, Kangwon National University, Chuncheon 200-701, Korea \\ ${ }^{3}$ Kenya Marine and Fisheries Research Institute (KMFRI), Kegati Aquaculture Research Station, P.O. Box 3259, Kisii, Kenya
}

\begin{abstract}
The Kenyan aquaculture sector is broadly categorized into freshwater aquaculture and mariculture. Whereas freshwater aquaculture has recorded significant progress over the last decade, the mariculture sector has yet to be fully exploited. The Kenyan aquaculture industry has seen slow growth for decades until recently, when the government-funded Economic Stimulus Program increased fish farming nationwide. Thus far, the program has facilitated the alleviation of poverty, spurred regional development, and led to increased commercial thinking among Kenyan fish farmers. Indeed, national aquaculture production grew from 1,000 $\mathrm{MT} / \mathrm{y}$ in 2000 (equivalent to $1 \%$ of national fish production) to $12,000 \mathrm{MT} / \mathrm{y}$, representing $7 \%$ of the national harvest, in 2010 . The production is projected to hit 20,000 MT/y, representing $10 \%$ of total production and valued at USD 22.5 million over the next 5 years. The dominant aquaculture systems in Kenya include earthen and lined ponds, dams, and tanks distributed across the country. The most commonly farmed fish species are Nile tilapia Oreochromis niloticus, which accounts for about $75 \%$ of production, followed by African catfish Clarias gariepinus, which contributes about $21 \%$ of aquaculture production. Other species include common carp Cyprinus carpio, rainbow trout Oncorhynchus mykiss, koi carp Cyprinus carpio carpio, and goldfish Carassius auratus. Recently, Kenyan researchers have begun culturing native fish species such as Labeo victorianus and Labeo cylindricus at the National Aquaculture Research Development and Training Centre in Sagana. Apart from limited knowledge of modern aquaculture technology, the Kenyan aquaculture sector still suffers from an inadequate supply of certified quality seed fish and feed, incomprehensive aquaculture policy, and low funding for research. Glaring opportunities in the Kenyan aquaculture industry include the production of live fish food, e.g., Artemia, daphnia and rotifers, marine fish and shellfish larviculture; seaweed farming; cage culture; integrated fish farming; culture of indigenous fish species; and investment in the fish feed industry.
\end{abstract}

Key words: Aquaculture, Kenya, Challenges, Opportunities, ESP, KMFRI

\section{Introduction}

Growth of the global aquaculture industry has been sporadic over the last 50 years, and the global production capabilities of culture and capture fisheries are almost comparable (Food and Agriculture Organization of the United Nations, 2012). The sporadic growth has been largely attributable to technological advancements in fish production, e.g., hybridization, genetic engineering, formulated diets, and biofloc technology used in ponds, cages, tanks, and recirculation systems (Food and Agriculture Organization of the United Nations, 2012). However, the rate of growth of global aquaculture has differed across
http://dx.doi.org/10.5657/FAS.2014.0001

(C) $\$$ This is an Open Access article distributed under the terms of
the Creative Commons Attribution Non-Commercial Licens
(http://creativecommons.org/licenses/by-nc/3.0/) which
permits unrestricted non-commercial use, distribution, and reproduction in
any medium, provided the original work is properly cited.
Received 14 August 2013; Revised 07 January 2014

Accepted 09 January 2014

*Corresponding Author

E-mail: wamaengo@yahoo.com 

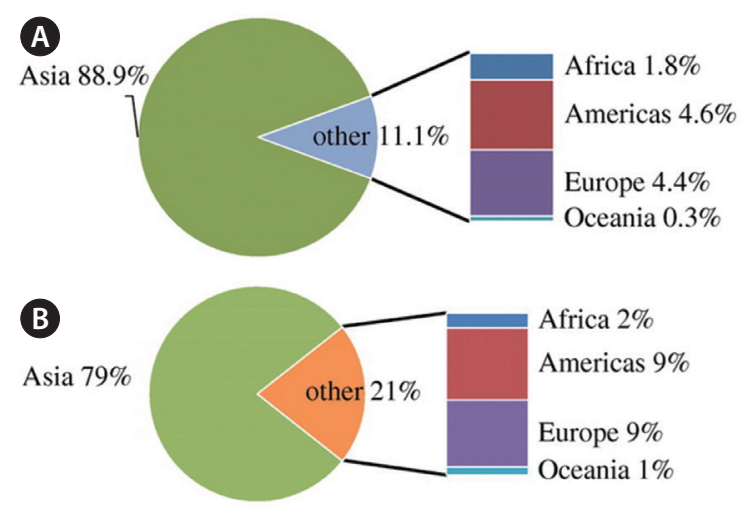

Fig. 1. Global aquaculture productions by region, (A) Aquaculture by quantity 2008 (excluding aquatic plants). (B) Aquaculture by value 2008 (excluding aquatic plants) (source: Food and Agriculture Organization of the United Nations, 2010).

continents. Whereas continental Asia has become the giant in aquaculture production, Africa has yet to report any significant quantities of aquaculture on the global scale despite the availability of enormous natural resources in some regions (Food and Agriculture Organization of the United Nations, 2010). Africa contributes only $1.8 \%$ of global aquaculture production (Fig. 1) (El-Sayed, 2006; Bostock et al., 2010; Food and Agriculture Organization of the United Nations, 2010), although African aquaculture is currently undergoing an exciting phase of growth after numerous false starts, perhaps as a reaction to the high incidence of poverty, malnutrition, and unemployment (Hecht, 2000). Africa has great potential for fish farming with $37 \%$ of its surface area suitable for artisanal fish farming and $43 \%$ for commercial fish production (Aguilar-Manjarrez and Nath, 1998).

Fish farming was first begun in Kenya by colonists in the early 1900s through introduction of trout in rivers for sport fishing (Ngugi et al., 2007). This progressed into static pond culture of species such as tilapia, common carp, and catfish in the 1920s (Maar et al., 1966). Indeed, the establishment of Sagana and Kiganjo fish farms for production of warm- and cold-water seed fish in 1948 was the beginning of small-scale rural fish farming in Kenya, which became popular in the 1960s (Ngugi and Manyala, 2004; Nyonje et al., 2011). Furthermore, "eat more fish campaigns" promoted by the government in the late 1960s also accelerated the interest in rural fish farming (Ngugi and Manyala, 2004; Ngugi et al., 2007). The primary cultured fish species in Kenya today are Nile tilapia (75\%) and African catfish (15\%) (Ngugi and Manyala, 2004), but efforts to introduce other indigenous fish, such as Labeo victorianus, in aquaculture have not been widely adopted by farmers. Mariculture was introduced in the late 1970s with the establishment of the Ngomeni Prawn Pilot Project (Nyonje et al., 2011). Unfortunately, the marine water fisheries remain underexploited, mainly due to accessibility problems, conflicts over land ownership, and lack of clear policies. Despite the enormous potential for fish farming in Kenya, aquaculture has been characterized by low levels of production that have stagnated at less than $1 \%$ of the country's protein needs over the past decade (Nyonje et al., 2011). This is due to many challenges, which will be addressed later in this paper. With population growth escalating to unsustainable levels and increasing food insecurity, Kenya's dwindling capture fisheries are unable to adequately provide cheap protein for the growing population. Natural water bodies, which have also been instrumental in fish production, have had their share of challenges, ranging from pollution to reduction of water levels that compromise fisheries (Lake Victoria Basin Commision, 2011; Obiero et al., 2012). In light of these problems, aquaculture is the best opportunity to bridge the escalating gap of supply and demand for fish. For aquaculture to register substantial growth and meet its potential, development of Kenyan aquaculture must be refocused. This paper explores the current status, challenges, potentials, and future opportunities for the Kenyan aquaculture sector. We focus on the potential of current aquaculture production systems and reveal opportunities for improvement. The current aquaculture species and inputs (feed and seed fish) in the Kenyan aquaculture sector are also discussed.

\section{Current Status of Kenyan Aquaculture}

Kenya is endowed with several inland natural water resources such as Lakes Victoria, Turkana, Baringo, Naivasha, Chala, Kanyaboli, and Jipe, among others. Major rivers include the Tana, Athi, Nyando, Nzoia, Gucha, Migori, Yala, and Mara. In addition to artificial water bodies from dams, which are spread across the landscape, Kenya boasts approximately $600 \mathrm{~km}$ of coastal shoreline with an Exclusive Economic Zone of 200 nautical miles, which could be harnessed to enhance aquaculture. Although most parts of the country are suitable for aquaculture, only about $0.014 \%$ of the 1.4 million ha of potential aquaculture sites are used for aquaculture and about $95 \%$ of fish farming is on a small scale (Otieno, 2011). In addition, fish farming has been practiced mostly in the central, Nyanza, western provinces, and parts of Rift Valley and coastal provinces (Nyonje et al., 2011).

Since the beginning of Kenyan aquaculture in the $1950 \mathrm{~s}$ until 2006, total annual aquaculture production has never exceeded 2,000 MT/y (Fig. 2). Prior to the government-funded Economic Stimulus Program (ESP), about 7,500 fish farmers, mostly from the Rift Valley and central provinces, held about 7,477 production units in an estimated area of 722.4 ha (Nyonje et al., 2011). By 2007, the mean yield from fish farming was approximately 5.84 $\mathrm{MT} \mathrm{yr}^{-1}$, compared to 4,452 MT of the total annual fish production, and was valued at $\$ 10.78$ million, accounting for only $3 \%$ of the total fish production (National Economic Survey, 2006). Recognizing aquaculture as one of the viable options for revamping the country's food sector, the 


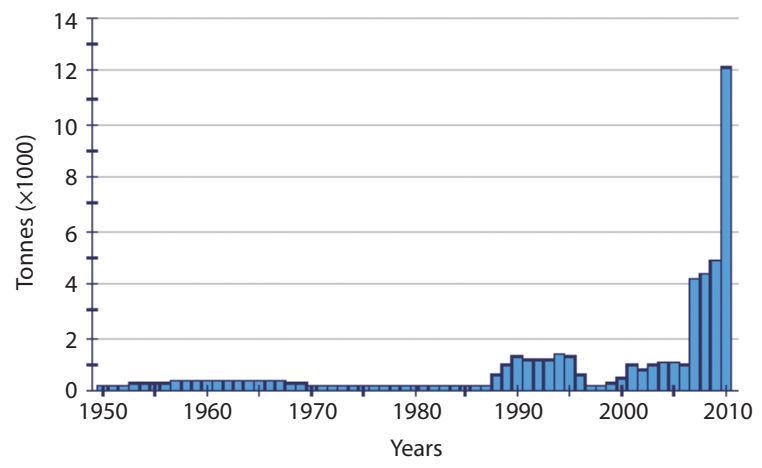

Fig. 2. Reported aquaculture production in Kenya (from 1950 to 2010) (source: Food and Agriculture Organization of the United Nations, 2010).

Kenyan government initiated the ambitious ESP in 2009 to stimulate economic development, foster economic recovery, alleviate poverty, and spur regional development (Nyonje et al., 2011). The Fish Farming Enterprise Productivity Program under the ESP was aimed at injecting commercial thinking into fish farming to build up a vibrant aquaculture industry. The program aimed to increase production of farmed fish from 4,000 MT to over 20,000 MT in the medium term and to more than 100,000 MT in the long term (Charo-Karisa and Gichuri, 2010). In the first year of the program, 200 fish ponds were constructed in each of 140 constituencies, totaling more than 27,000 fish ponds nationally (Charo-Karisa and Gichuri, 2010; Musa et al., 2012). This triggered an immediate shortterm demand for about 28 million certified tilapia and catfish fingerlings and over 14,000 MT of formulated fish feeds, which could not be adequately and timely supplied, even by the private sector (Musa et al., 2012). The ripple effect of the ESP led some farmers to dig their own ponds, further increasing the demand for seed fish and feed to over 100 million and 100,000 MT, respectively (Charo-Karisa and Gichuri, 2010; Musa et al., 2012). Apart from the effects of the ESP, most people who abandoned subsistence farming for fish farming, and new farmers practicing commercial aquaculture, now own bigger ponds, resulting in higher yields (Otieno, 2011).
Indeed, current national aquaculture production, including harvests from the ESP and other private farms, is estimated at $12,000 \mathrm{MT} / \mathrm{y}$ (Fig. 2), equivalent to $7 \%$ of the total production and valued at \$21 million (Nyonje et al., 2011). Production is projected to hit $20,000 \mathrm{MT} / \mathrm{y}$, representing $10 \%$ of national fish production, in the next 5 years (Nyonje et al., 2011). This presents a lucrative opportunity for aquaculture development in the feed and seed fish sectors, which unfortunately still suffer from basic problems.

To date, the Kenyan government has designated several aquaculture facilities in various parts of the country to serve as research centers, training facilities, and sources of fingerlings and feed for fish farmers. They include the National Aquaculture Research Development \& Training Center (NARDTC) in Sagana, Kisii fish farm training center, Kiganjo trout farm, Ndaragua trout farm, Chwele fish farm, Lake Basin Development Authority (LBDA) in Kisumu, Wakhungu fish farm in Busia, Sangoro research station, Kegati research station, and Kabonyo and Ngomeni fish farms. However, most of these centers lack basic laboratory equipment and human capacities to spur significant aquaculture development in their respective spheres of influence.

\section{Productivity of Aquaculture Systems in Kenya}

Like in other African countries, fish farming in Kenya has been extensive but less intensive (Ngugi et al., 2007). Intensive fish farming is unpopular due to the high cost of infrastructure advancements and the knowledge needed. However, some farmers on the outskirts of major towns and cities are becoming more receptive up to recirculating aquaculture systems, technologies that can help tap into the lucrative fish market in cities. The motivation for this is due to high production capacities within a small area, since land around the cities is expensive. The fish farmer's decision of the optimal culture method is influenced largely by environmental, economic, and managerial challenges that pose problems for many fish farmers (De Graaf et al., 2005). Table 1 shows the current num-

Table 1. The Kenya national distribution of fish culture systems and the respective cover area $\left(\mathrm{m}^{2}\right) 2009$

\begin{tabular}{|c|c|c|c|c|c|c|c|c|c|}
\hline \multirow{2}{*}{ Province } & \multirow{2}{*}{$\begin{array}{l}\text { No. of } \\
\text { farmers }\end{array}$} & \multicolumn{2}{|c|}{ Ponds } & \multicolumn{2}{|c|}{ Dams } & \multicolumn{2}{|c|}{ Tanks } & \multicolumn{2}{|c|}{ Total } \\
\hline & & No. & Area & No. & Area & No. & Area & No. & Area \\
\hline Central & 1,339 & 1,609 & 506,605 & 167 & $1,933,809$ & 83 & 18,744 & 1,859 & $2,459,158$ \\
\hline Coast & 184 & 434 & 58,698 & - & - & 9 & 180 & 434 & 58,698 \\
\hline Eastern & 538 & 752 & 423,628 & 20 & 113,018 & 3 & 118 & 775 & 536,764 \\
\hline Nyanza & 1,360 & 2,070 & 453,423 & 15 & 41,220 & 1 & 27 & 2,086 & 494,670 \\
\hline R. Valley & 1,242 & 1,531 & 761,856 & 129 & $3,385,298$ & 65 & 4,015 & 1,725 & $4,151,169$ \\
\hline Western & 1,665 & 2,720 & 549,486 & - & - & - & - & 2,720 & 549,486 \\
\hline Total & 6,328 & 9,116 & $2,753,696$ & 331 & $5,473,346$ & 161 & 23,085 & 9,608 & $8,250,127$ \\
\hline
\end{tabular}

Source: Otieno (2011). 


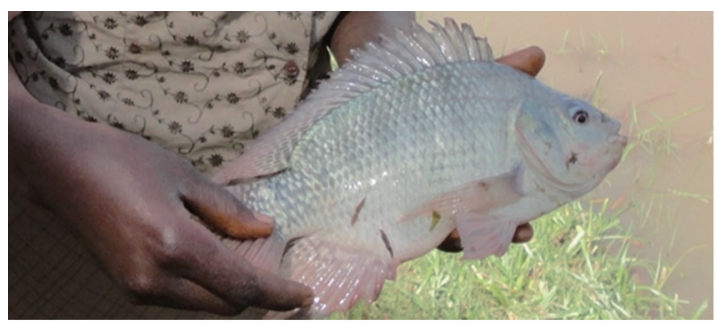

Nile tilapia Oreochromis niloticus

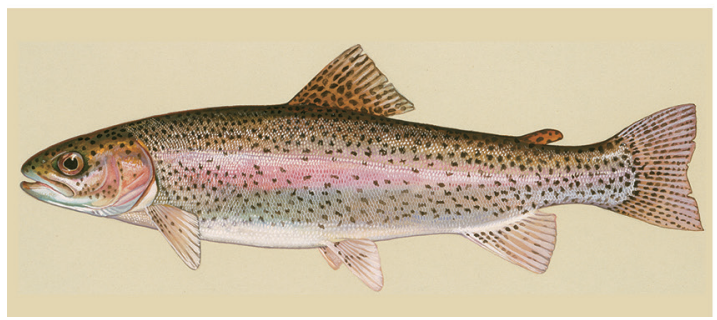

Trout Oncorhynchus mykiss

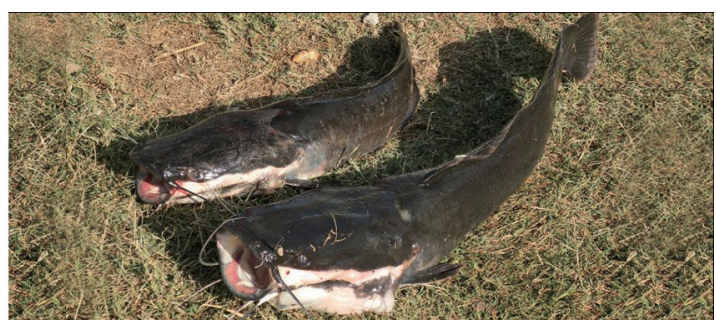

African catfish Clarias gariepinus

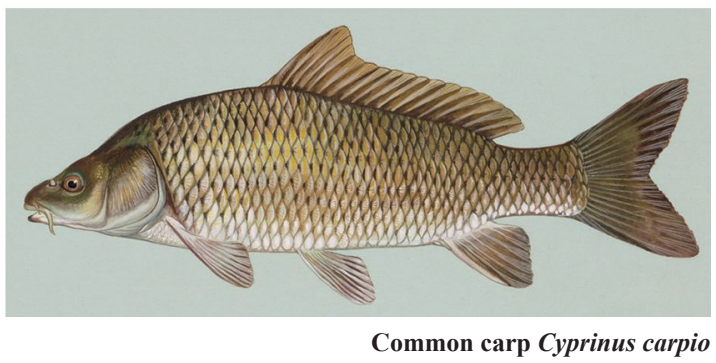

Fig. 3. The plate showing the commonly farmed freshwater fishes in Kenya.

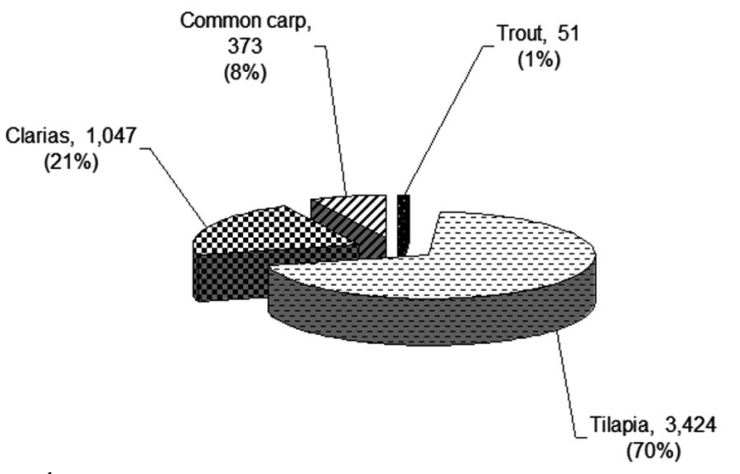

Fig. 4. Aquaculture production by species in 2009 (adapted from Otieno, 2011). Fish culture in the earthen and Liner ponds.

ber of fish culture systems in Kenya as a result of the effects of ESP and its ripple effects. The absence of data from other systems, such as cages, recirculating systems, and raceways, is a clear indication that the Kenyan aquaculture sector has room for expansion. Indeed, these are some of the areas that could be lucrative not only to local investors but also foreign investors.

As late as 2011, about 5,000 tons of various farmed fish species (Fig. 3) valued at $\$ 12.3$ million were harvested (Otieno, 2011). As usual, tilapia Oreochromis niloticus contributed the bulk of the fish, yielding about 3,400 tons (69.9\%), followed by African catfish Clarias gariepinus at 1,047 tons (21\%), common carp Cyprinus carpio at 373 tons, and trout Oncorhynchus mykiss at 51 tons (Fig. 4). Other farmed fish that were harvested in small quantities included black bass, koi carp, and goldfish (Otieno, 2011). Recognizing that the production of currently farmed fish species in Kenya depends on the productivity of the farming systems used is important. As of now, pond culture is dominant.

\section{Fish Culture in Earthen and Lined Ponds}

Fish farming in earthen ponds has been advocated for the development of cheap food resources in developing nations (Food and Agriculture Organization of the United Nations, 2000). Over $90 \%$ of cultured fish in Sub-Saharan Africa come from earthen ponds of between 200 and $500 \mathrm{~m}^{2}$ (Ngugi et al., 2007; Mucai et al., 2011), where fish are fed primarily with locally available low cost agricultural by-products. This method of fish culture is popular in Kenya due to the low cost of establishment and generally good soil in most places, e.g., in the western province (Musa et al., 2012). In places where the soil is not suitable, farmers have been encouraged to buy Ultraviolet-treated liners to reduce water loss through seepage. However, this option is too expensive for the majority of farmers. In such areas, we suggest that recirculating aquaculture should be encouraged through government and private sector initiatives. Fish ponds in Kenya range from small dug holes to designed ponds with inlet and outlet channels (Fig. 5) and harvest basins yielding approximately 1-2 tons/ha/y under competent management (Brummett and Noble, 1995). Despite its commonality, pond culture has not been fully exploited and most production in rural yards is unreported. Tilapia ponds can be managed intensively or semi-intensively, depending on whether fertilizers and complete feeding are applied. Some fish farmers still embrace low productivity systems of culture, where ponds are naturally stocked by flooding from rivers and lakes (Denny et al., 2006). 

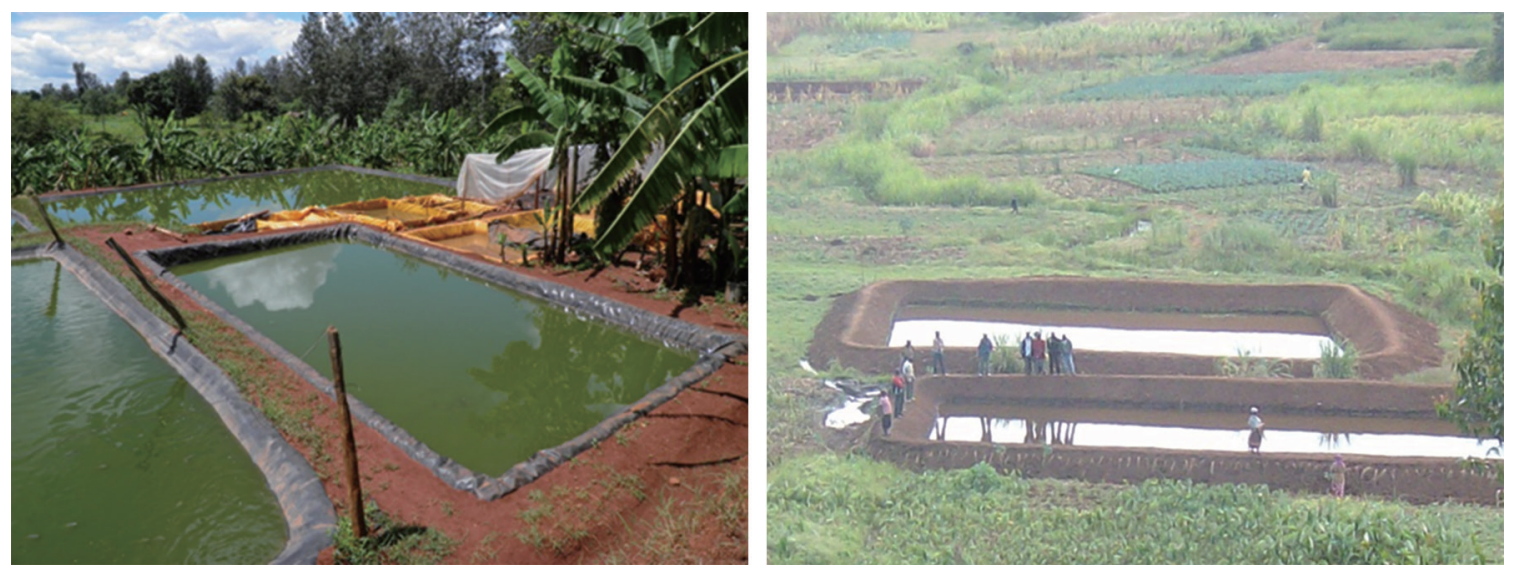

Fig. 5. The plate showing liner and earthen ponds in Kenya. Picture by Jonathan Mbonge Munguti.

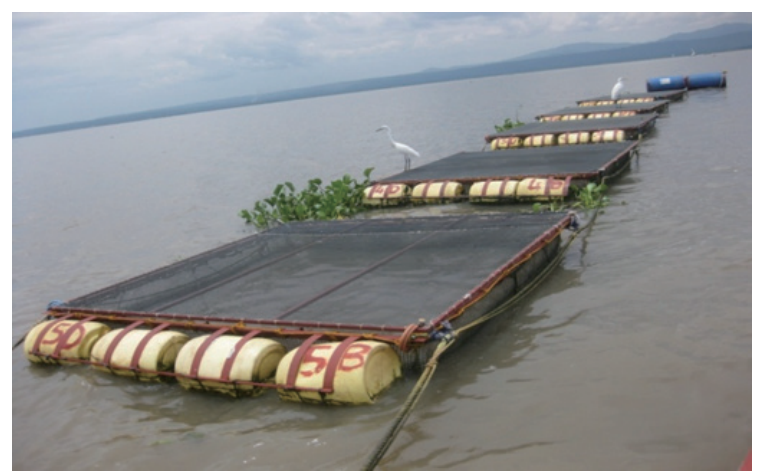

Fig. 6. The plate showing tilapia cages in Dunga beach, Lake Victoria, Kenya. Picture by Erick Ochieng Ogello.

\section{Tank Fish Farming}

In cases of land and water scarcity but favorable economic conditions, tank farming is a good alternative to ponds or cages. Tests have shown that fish can be grown at high densities in the confinement of tanks under quality management (Rakocy, 1989). During the production cycle, high fry stocking density is reduced at regular intervals to minimize crowding and ensure good water quality. Tank fish farming in Kenya is limited. In fact, we could find no literature to confirm the existence of fish tank farming in Kenya, which could be due to operational limitations, but it provides an unexploited opportunity for investment.

\section{Cage fish farming}

Fish farming in cages is done in existing water bodies (ponds, rivers, lakes, dams, and oceans). The fish are enclosed in a cage that allows free water exchange. Only strong, du-

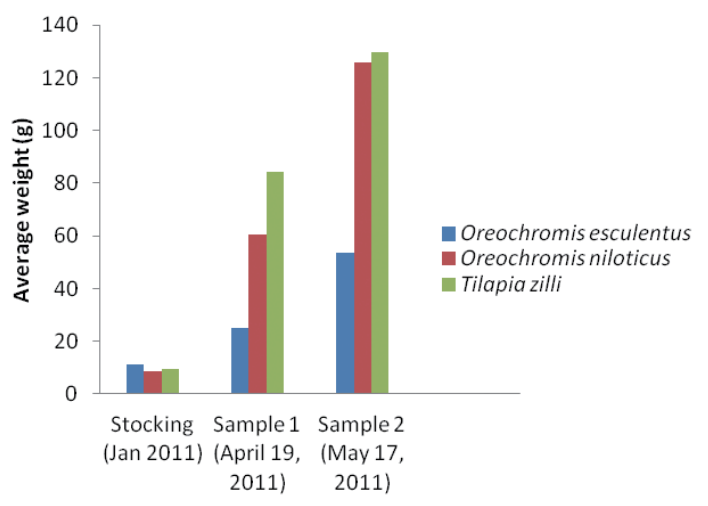

Fig. 7. Mean weight (g) of different tilapia species stocked in $8 \mathrm{~m}^{3}$ cages at density of 100 fishes $/ \mathrm{m}^{3}$ in Lake Victoria, Kenya.

rable, and nontoxic materials are used to construct the cages, which vary in size and shape. The location of the cage in the water body may be critical for proper water circulation. Although little information is available on cage culture in Kenya, it may be an overlooked asset in the aquaculture sector. As fish cage culture in Lake Victoria has begun relatively recently, productivity data are largely lacking. Over the last 3 years, the Kenya Marine and Fisheries Research Institute (KMFRI) initiated preliminary trials of tilapia cage culture off Dunga beach in Kisumu, where impressive growth of Oreochromis niloticus, Oreochromis esculentus, and Tilapia zilli were reported (Fig. 6). Different species of mixed sex tilapia from the selected breeding program in Sagana were cultured in $8-\mathrm{m}^{3}$ cages in Lake Victoria. Preliminary results showed that $O$. $n i$ loticus performed better than the native $O$. esculentus, gaining $175 \mathrm{~g}$ within 4 months compared to $150 \mathrm{~g}$ for T. zilli (Fig. 7). Further opportunities exist for development of cage culture in Kenya by using improved fish species such as genetically improved farmed tilapia (GIFT). 

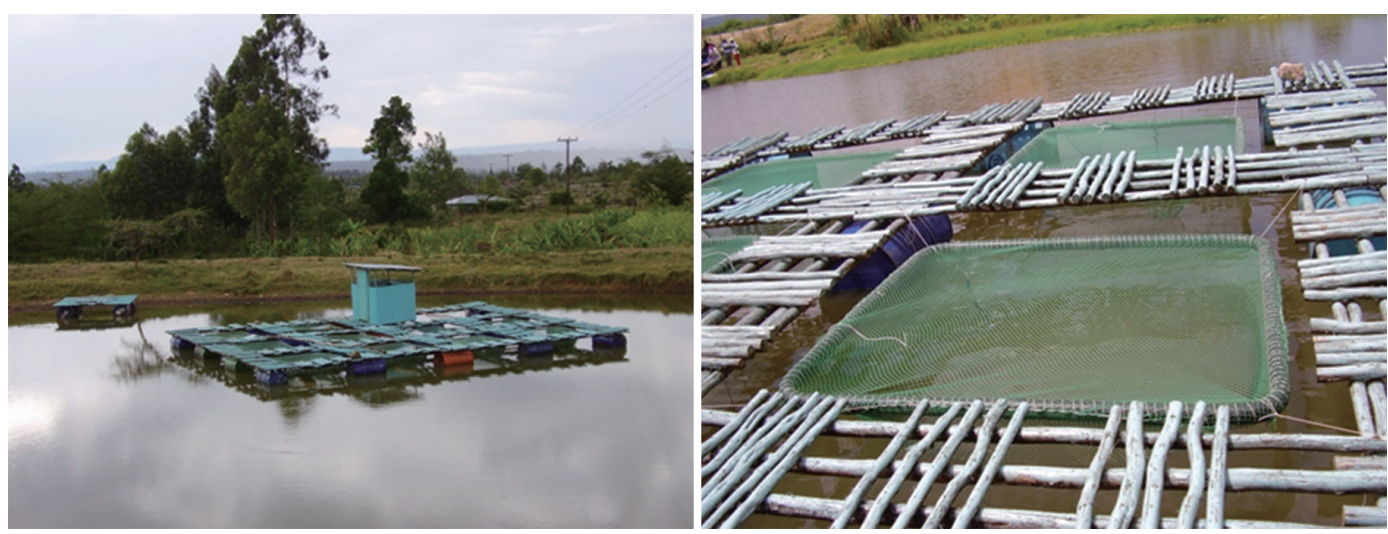

Fig. 8. The plate showing tilapia BOMOSA cages Ngeki dam in Machakos County, Kenya. Picture by Jonathan Mbonge Munguti.

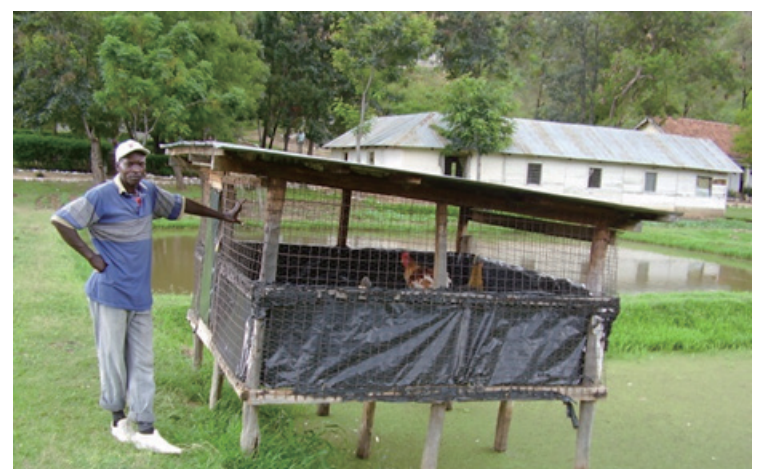

Fig. 9. The plate showing integrated fish farming at Sangoro Kenya Marine \& Fisheries Research Institute Picture by Jonathan Mbonge Munguti.

\section{Fish farming in dams}

The construction of dams was also encouraged under the ESP, not only to provide water but also to encourage communal fish farming activities. Fish farming in dams is not very popular in Kenya and thus not well documented. However, dams have been used to house cages for experimental and research activities, such as the recently completed regional BOMOSA (2009) project, a multidisciplinary research project funded by the European Union (Fig. 8). This is another area that has not been fully exploited in Kenyan aquaculture.

\section{Integrated fish farming}

An integrated fish culture approach involves the connection of agricultural systems to fish farming in a design that allows waste from one system to be used as input in another system, conserving resources and boosting returns (Edwards, 1980; Chen, 1989; Ayinla, 2003; Shoko et al., 2011). Through its biophysical and socioeconomic benefits, integrated fish farming has immense potential to address income instability, nutritional insecurity, unemployment, and poverty of farmers, not only in Kenya, but across East Africa (Ogello et al., 2013). Integrated fish farming is inexpensive and profitable and is another overlooked asset for present and future aquaculture development in the East African region (Ogello et al., 2013).

In Kenya, integrated fish culture is still in nascent stages of development with demonstrational infrastructure present in state-owned institutions such as the LBDA in Kisumu and the KMFRI in Sagana and Sangoro (Fig. 9). Nevertheless, farmers have embraced the practice across the country where they use mainly chicken and cow manure for pond fertilization, and have recorded impressive performance in some areas (Ogello and Opiyo, 2011; Ogello et al., 2013). Studies on integrated fish culture on the Kenyan side of the Lake Victoria Basin reported that a $200 \mathrm{~m}^{2}$ fish pond of $O$. niloticus fertilized with cow manure provided an additional per capita fish supply of $3.4 \mathrm{~kg}$ to a household of seven people for an average annual productivity of about $200 \mathrm{~kg} / \mathrm{ha} / \mathrm{y}$ (Denny et al., 2006). However, this is a low-intensity system in which no feed is supplied. In the recently funded fish farming ESP project, no funds were allocated to the integrated fish farming despite its enormous potential.

\section{Current Status of the Kenyan Fish Feed Industry}

Fish feed is a key component in any fish-farming venture because fish nutrition accounts for $40-50 \%$ of the total variable production costs on the fish farm (Craig and Helfrich, 2002; Munguti and Charo-Karisa, 2011). One of the most pressing current challenges in Kenyan aquaculture is the lack of efficient and inexpensive farm-made feeds for different stages of fish development (Munguti et al., 2012). In reaction to the ESP project, the Kenyan fish feed sector experienced a shortage of 
14,000 MT/y (Charo-Karisa and Gichuri, 2010). Since then, demand has increased tremendously to about 50,000 MT/y. Due to the increased demand for fish feed, unscrupulous dealers sometimes sell feed of compromised quality, prompting the government to initiate efforts to establish national standards for fish feed. The fish feed standards (Table 2) were a culmination of several meetings and negotiations between all aquaculture stakeholders: the KMFRI, the Ministry of Fisheries, commercial feed companies, fish farmers, and the Kenya Bureau of Standards (KBS).

Most fish farmers in Kenya add manure or inorganic fertilizer to ponds because it increases the supply of natural food

Table 2. The Kenyan commercial fish feed standards for catfish and tilapia fry, fingerlings, growers and brooders

\begin{tabular}{|c|c|c|c|c|}
\hline Feed parameters & Fry & Fingerlings & Growers & Brooders \\
\hline Feeding rate & $5 \%$ b.w & $6-8 \%$ b.w & $3 \%$ b.w & $3 \%$ b.w \\
\hline Crude protein (\%) & $40-45 \%$ & $35-40 \%$ & $30-34 \%$ & $40 \%$ \\
\hline Energy $(\mathrm{MJ} / \mathrm{kg})$ & $\geq 10$ & $\geq 10.5-11$ & $\geq 11.5-12.5$ & \\
\hline Crude fiber CF (\%) & $\geq 4$ & $\geq 4$ & $\geq 6$ & $\geq 6$ \\
\hline Lipids (\%) & $\geq 8$ & $\geq 8$ & $\geq 10$ & $\geq 10$ \\
\hline Lysine $(\%)$ & $\geq 12$ & $\geq 12$ & $\geq 12$ & $\geq 12$ \\
\hline Methionine (\%) & $\geq 5$ & $\geq 5$ & $\geq 5$ & $\geq 5$ \\
\hline Shelf life (mo) & $\geq 6$ & $\geq 6$ & $\geq 6$ & $\geq 6$ \\
\hline Moisture content $(\%)$ & $\leq 12$ & $\leq 12$ & $\leq 12$ & $\leq 12$ \\
\hline Enzymes & \multicolumn{4}{|c|}{ Needed to improve the FCR } \\
\hline Pellet size (mm) & Mash & 2 & $2-5$ & $2-5$ \\
\hline Floating pellets (min) & N/A & $\geq 2$ & $\geq 2$ & $\geq 2$ \\
\hline Packaging labels & \multicolumn{4}{|c|}{ Company address, manufacturing and expiry date } \\
\hline Packaging size & \multicolumn{4}{|c|}{$5 \mathrm{~kg}, 10 \mathrm{~kg}, 20 \mathrm{~kg}, 50 \mathrm{~kg}$, etc. } \\
\hline Packaging material & \multicolumn{4}{|c|}{ Must be airtight } \\
\hline Acidifiers & \multicolumn{4}{|c|}{ Preferred } \\
\hline Premix (vitamin and mineral) & \multicolumn{4}{|l|}{ Mandatory } \\
\hline
\end{tabular}

Courtesy of ESP aquaculture working group 2012-2013.

Table 3. Authenticated feed suppliers in Kenya

\begin{tabular}{|c|c|c|c|}
\hline Company name & Address & Region/Location & Director/Contact (tel no.) \\
\hline Sigma Feeds Ltd. Co. & $\begin{array}{l}\text { P.O. Box } \\
18138 \text { Nairobi }\end{array}$ & Isinya /Namanga Road, Kajaido & $\begin{array}{l}\text { Shah Kirtesh } \\
+254-0733600895\end{array}$ \\
\hline Uga Fish Feeds Kenya Ltd. & $\begin{array}{l}\text { P.O. Box } \\
\text { 31833-00600 Nairobi }\end{array}$ & Industrial Area, off enterprise road & $\begin{array}{l}\text { Dr. E. Onyango } \\
\quad+254-020-2634081\end{array}$ \\
\hline Economy Farm Products Kenya Ltd. & $\begin{array}{l}\text { P.O. Box } \\
\quad 64983-00620 \text { Nairobi }\end{array}$ & Nanyuki Rd. Industrial Area, Nairobi & $\begin{array}{l}\text { John Gathongo } \\
\quad+254-00202013366\end{array}$ \\
\hline Maisha Bora Fish Feeds Ltd. & $\begin{array}{l}\text { P.O. Box } \\
\quad 60803-00200 \text { Nairobi }\end{array}$ & Kikuyu, Nairobi & $\begin{array}{l}\text { Gilbert Gathuo } \\
\quad+254-020-2511824\end{array}$ \\
\hline Thoyu Feed Ltd. & $\begin{array}{l}\text { P.O. Box } \\
\quad 4491-20100 \text { Nakaru }\end{array}$ & Sungura road Industrial Area & $\begin{array}{l}\text { Priscilla Nduta } \\
\quad+245728427898\end{array}$ \\
\hline Kwality Fish Feeds Limited & $\begin{array}{l}\text { P.O. Box } \\
\text { 71-00200- Nairobi }\end{array}$ & Off Ruiru Kiambu Road & $\begin{array}{l}\text { Peter Cotti } \\
\quad+254-721274386\end{array}$ \\
\hline \multicolumn{4}{|l|}{ Cottage feed industries } \\
\hline Othaya Fish Feeders S.H.G & $\begin{array}{l}\text { P.O. Box } \\
82 \text { Othaya }\end{array}$ & Othaya & $\begin{array}{l}\text { Moses Ndungu } \\
\quad+254-0726849170\end{array}$ \\
\hline Chumara Fish Feeds & $\begin{array}{l}\text { P.O. Box } \\
353 \text { Chuka }\end{array}$ & Chuka & $\begin{array}{l}\text { John Marangu } \\
\quad+254-0735628971\end{array}$ \\
\hline Bidii Fish Farmers S.H.G & $\begin{array}{l}\text { P.O. Box } \\
215 \text { Luanda }\end{array}$ & Luanda- Emuhaya & $\begin{array}{l}\text { George Ambuli } \\
0723117706\end{array}$ \\
\hline Osifeeds Ltd. & $\begin{array}{l}\text { P.O. Box } \\
\text { 134-00606 Nairobi }\end{array}$ & Kajiado & $\begin{array}{l}\text { Susan Kisoso } \\
0720751859\end{array}$ \\
\hline Zibag Fish producers \& Processors & $\begin{array}{l}\text { P.O. Box } \\
\text { 1333, Nyahururu }\end{array}$ & Nyandarua & $\begin{array}{l}\text { DFO Nyahururu } \\
0721622474\end{array}$ \\
\hline $\begin{array}{l}\text { Hesao Integrated Fish Farming } \\
\text { Organization }\end{array}$ & $\begin{array}{l}\text { P.O. Box } \\
3844 \text { Kisumu }\end{array}$ & Nyalenda B & $\begin{array}{l}\text { Richard Okongo } \\
0722620169\end{array}$ \\
\hline
\end{tabular}

Courtesy of ESP aquaculture working group 2012/2013. 
organisms. Commercial fish feeds for tilapia usually contain 24-28\% crude protein (Liti et al., 2006) but are too expensive for most farmers. Therefore, most farmers prefer locally mixed feeds, such as a combination of $76 \%$ rice bran and $24 \%$ fish meal, which is a mix of dried freshwater shrimp Caridina spp., or maize bran, sometimes with some Omena Rastrineobola argentea meal added (Ngugi et al., 2007). Based on studies by Liti et al. (2006), fish fed maize or wheat bran grew significantly faster than those fed rice bran. Maize bran is better than wheat bran because of lower levels of fiber.

Due to the low quality of fish feeds in the Kenyan aquaculture market, the ESP nutrition team, together with other aquaculture stakeholders, established a vetting process for fish feed manufacturers. To date, 15 fish feed firms have been approved, but further survey efforts are under way to identify more firms (Table 3).

\section{Current Status of the Seed Fish Sector}

Insufficient availability and quality of fingerlings for stocking are key constraints for the development of Kenyan aquaculture. In addition to the escalating demand for African catfish $C$. gariepinus fingerlings for stocking fish ponds, this species is also used as bait fish in capture fisheries, leading to increased demand every year (Ngugi et al., 2007). As of 2007, the Fisheries Department estimated that the annual demand for catfish fingerling in Lake Victoria was 10 million/y for aquaculture and 18 million/y for bait (Ngugi et al., 2007). Today, the total demand for both catfish and tilapia fingerling is estimated at 100 million $\mathrm{yr}^{-1}$ (Charo-Karisa and Gichuri, 2010). Despite governmental efforts to improve existing fish breeding centers, this huge annual demand for fingerlings cannot be attained unless further development by the private sector. In addition, the quality of the fingerling supplied needs to be ensured. To achieve good quality seed fish, aquaculture experts have encouraged measures to obtain same-sex fingerlings using sex reversal and hybridization techniques. However, such initiatives are still unpopular among fish farmers due to the technical knowledge and facilities required. These are some areas that private investors could link to support fish farming in Kenya. So far, the Kenyan government through the aquaculture working group which brings together researchers, fisheries officers, fish farmers, Kenya Bureau of Standards (KBS), and other stakeholders has authenticated fish hatcheries nationwide and are in the process of drafting seed fish quality standards, which are expected to solve problems of substandard seed fish in the aquaculture market.

\section{Challenges in the Kenyan Aquaculture Sector}

Unfortunately, after many years of fish farming in Kenya, the country is still suffering from basic challenges. The Ke- nyan aquaculture industry suffers from limited knowledge of aquaculture investment (Ngugi and Manyala, 2004) and lack of information on the economic performance of various fish farming systems (Kaliba et al., 2007). More importantly, the inadequate supply of certified quality feed and seed fish has been a longstanding hurdle to the growth of aquaculture. Farmers have given up fish farming because they run into huge losses after stocking their ponds with low-quality fingerlings and substandard feed. Other factors affecting the growth of aquaculture include lack of a comprehensive aquaculture policy, poor extension services, lack of robust needbased research coupled with low funding, lack of investment by the private sector, and unfocused promotion of aquaculture through many institutions (Gitonga et al., 2004). Indeed, improvements in fish culture systems, such as increasing pond productivity, introducing other efficient systems, and developing a sustainable mechanism for production and distribution of pond inputs, are challenges that still need to be addressed. With the explosive interest in fish farming stimulated by the ESP, new challenges from environmental pollution, biosecurity, and the spread of diseases are likely to emerge in the near future.

\section{Opportunities for Present and Future Aquaculture Development}

The major problem with marine fish larviculture is the lack of proper food that contains all the essential nutrients required by fish larvae, which has led to mass mortalities up to $100 \%$ (Sorgeloos, 1980). Recently, a great opportunity has presented itself on the Kenyan coast, thanks to the permanent establishment of a population of Artemia, due to cooperation between the KMFRI and the Belgian government (Mremi, 2011; Kapinga, 2012; Ogello, 2013). Artemia is a live food with excellent nutrition for the development of marine fish larvae (Sorgeloos, 1980) and is small enough for larval fish to ingest (Sorgeloos et al., 1995). This is an excellent opportunity to increase food production and create employment through enhancing emerging mariculture initiatives, such as mullet, milkfish, and prawns, which seem to perform better in ponds than in natural waters (Bardach et al., 1972). Culture of shrimp and shellfish, such as mussels, oysters, and abalone, has not been initiated. The global estimate of the annual Artemia cyst market to feed fish and shellfish is over 2,000 tons, costing about $65 \mathrm{USD} / \mathrm{k}$ (Dhont and Sorgeloos, 2002). Shrimp hatcheries consume 80$85 \%$ of total sales, mainly in China, Southeast Asia, Ecuador, and other Latin American countries. Kenya can emulate the success of Vietnam, which has become one of the leading traders in Artemia cysts in the world market. Indeed, Artemia farming could be a gold mine. Kenya has the opportunity to exploit this opportunity and join other world leaders in the Artemia cyst trade. 


\section{Seaweed farming}

Kenya has a relatively lengthy coastline endowed with a wide variety of habitats for seaweed communities, much more so than other regions of tropical Africa (John and Lawson, 1997; Bolton et al., 2003). Kenyan seaweeds are relatively well documented (Bolton et al., 2007) in a checklist that includes a total of 386 species (214 red algae, 116 green algae, and 56 brown algae), plus an additional 19 intraspecific taxa (Bolton et al., 2007). Data on the Indian Ocean indicate that Kenya produces a group of seaweeds different from Tanzania, Madagascar, Mozambique, and the Indian Ocean coast of South Africa (Bolton et al., 2003, 2007). Through the KMFRI, research on seaweeds is currently ongoing, and great potential exists in marine-based seaweed farming. Indeed, the commercial viability of seaweed farming has a market potential that could put Kenya on par with countries such as Tanzania and Zanzibar. The growth of seaweed farming was recently captured in one of the Kenyan leading newspapers. The Standard reported in July 2013 that farmers along the Kenyan coast are embracing seaweed farming. This is a shift from fishing, where stocks have dwindled over recent years. Seaweed sells for $\$ 141.20$ ton $^{-1}$, which has enabled local communities to improve their lives tremendously.

\section{Indigenous freshwater aquaculture species}

Before the introduction of Nile perch Lates niloticus in Lake Victoria, two tilapia species (O. esculentus and Oreochromis variabilis) and other fish, such as Bagrus docmac, Labeo spp., Synodontis spp., and Protopterus spp., were the main species in the Lake Victoria fishery (Kudhongania and Kitamwebwa, 1995). Today, most of these lucrative indigenous species have been eliminated by Nile perch (Ogutu-Ohwayo, 2004). Spirited efforts have been made by the KMFRI to restore some of these native fish species through aquaculture initiatives. Recent cage culture trials of the native $O$. esculentus and $O$. variabilis in Lake Victoria showed that native fish can perform well in aquaculture systems. In addition, the KMFRI has pushed attempts to domesticate and culture Labeo victorianus at Sangoro and Kegati research stations. Even though little success can be reported, research efforts are on course. Local communities still recognize and attach strong economic value to the native fish species, and we believe this is another lucrative opportunity yet to be exploited in Kenyan aquaculture.

\section{Conclusion and Recommendations}

The much reported decline of capture fisheries in Kenyan natural waters is a clear indication that aquaculture needs to alleviate the burden of fish shortages. The great potential of Kenyan aquaculture cannot be emphasized enough. Indeed, the increased interest in aquaculture following the ESP is a testament that much more can be achieved when stakeholders work together. The successful development of sustainable aquaculture lies in the promotion of aquaculture as a viable investment opportunity whereby potential investors identify opportunities to make economic gains in a "win-win" fashion. As noted here, the marine sector harbors the most lucrative opportunities and should be given special focus. Other farming systems, such as integrated fish farming and cage culture, are underappreciated assets for present and future development of sustainable aquaculture in Kenya. A need exists to create linkages and collaboration among all stakeholders (research institutions, universities, fish farmers, nongovernmental organizations (NGOs), civil society, government officials, and policy makers) by creating a strong forum for exchange of information. Mechanisms must also be developed to link small farmers to local, urban, regional, and global markets. Rural schools are needed to educate farmers and strengthen their capacities to adopt new aquaculture technologies. Governments must create an environment to enable the private sector to invest in strategic areas. Specific and pragmatic policies should be tailored to effectively respond to local aquaculture conditions instead of impractical highly intensive aquaculture systems.

\section{References}

Aguilar-Manjarrez J and Nath SS. 1998. A Strategic Reassessment of Fish Farming Potential in Africa. CIFA Technical Paper 32. FAO, Rome, IT.

Ayinla OA. 2003. Integrated fish farming: a veritable tool for poverty alleviation/hunger eradication in the Niger Delta Region. In: Conference Proceedings of Fisheries Society of Nigeria. Eyo AA and Atanda JO, eds. Fisheries Society of Nigeria, Owerri, NG, pp. 40-41.

Bardach JE, Ryther JH and McLarney WO. 1972. Aquaculture the Farming and Husbandry of Freshwater and Marine Organisms. John Wiley \& Sons Inc., London, GB.

Bolton JJ, DeClerck O and John DM. 2003. Seaweed diversity patterns in Sub-Saharan Africa. In: Proceedings of the Marine Biodiversity in Sub-Saharan Africa: The Known and the Unknown. Decker C, Griffiths CL, Prochazka K, Ras C and Whitfield A, eds. Cape Town, ZA, pp. 229-241.

Bolton JJ, Oyieke HA and Gwada P. 2007. The seaweeds of Kenya: checklist, history of seaweed study, coastal environment, and analysis of seaweed diversity and biogeography. S Afr J Bot 73, 76-88. http://dx.doi.org/10.1016/j.sajb.2006.08.006.

BOMOSA. 2009. Integrating BOMOSA cage fish farming systems in reservoirs, ponds and temporary water bodies in Eastern Africa. Project No. 032103. BOMOSA.

Bostock J, McAndrew B, Richards R, Jauncey K, Telfer T, Lorenzen K, Little D, Ross L, Handisyde N, Gatward I and Corner R. 2010. Aquaculture: global status and trends. Philos Trans R Soc B 365, 2897-2912. http://dx.doi.org/10.1098/rstb.2010.0170. 
Brummett RE and Noble R. 1995. Aquaculture for African smallholders. ICLARM Technical Report 46. ICLARM, Manila, PH.

Charo-Karisa H and Gichuri M. 2010. Overview of the Fish Farming Enterprise Productivity Program. In: End of Year Report Fish Farming Enterprise Productivity Program Phase I. Aquaculture Development Working Group Ministry of Fisheries Development, Nairobi, KE.

Chen FY. 1989. Chicken Farming in integrated fish farming. Regional Aquaculture Center Wuxi China. NACA Tech Man 11, 4-30.

Craig S and Helfrich LA. 2002. Understanding Fish Nutrition, Feeds and Feeding. Virginia Creative Extension, Petersburg, VA, US, pp. 26-27.

De Graaf GJ, Dekker PJ, Huisman B and Verreth JAJ. 2005. Simulation of Nile tilapia (Oreochromis niloticus niloticus L.) culture in ponds, through individual-based modelling, using a population dynamic approach. Aquac Res 36, 455-471.

Denny P, Kipkemboi J, Kaggwa R and Lamtane H. 2006. The potential of Fingerpond systems to increase food production from wetlands in Africa. Int J Ecol Environ Sci 32, 41-47.

Dhont J and Sorgeloos P. 2002. Applications of Artemia. In: Artemia Basic and Applied Biology. Abatzopoulos TJ, Beardmore JA, Clegg JS and Sorgeloos P, eds. Kluwer Acadamic Publishers, Dordrecht, NL, pp. 251-257.

Edwards P. 1980. A review of recycling organic wastes into fish, with emphasis on the tropics. Aquaculture 21, 261-279. http://dx.doi. org/10.1016/0044-8486(80)90136-2.

El-Sayed AFM. 2006. Tilapia Culture. CABI Publishing, Wallingford, GB.

Food and Agriculture Organization of the United Nations. 2000. Small Ponds Make a Big Difference. Integrating Fish with Crop and Livestock Farming. Farm Management and Production Economics Service Inland Water Resources and Aquaculture Service. FAO, Rome, IT.

Food and Agriculture Organization of the United Nations. 2010. Securing Sustainable Small-Scale Fisheries: Bringing Together Responsible Fisheries and Social Development. RAP Publication 2010/19. In: APFIC/FAO Regional Consultative Workshop. Food and Agriculture Organization of the United Nations, Bangkok, TH, pp. $1-56$.

Food and Agriculture Organization of the United Nations. 2012. The State of World Fisheries and Aquaculture 2012. FAO, Rome, IT.

Gitonga NK, Mbugua H and Nyandati B. 2004. New approach to fish farming extension in Kenya. In: Samaki News: A magazine of the Department of Fisheries of Kenya. Vol. 3. No. 1. Motif Creative Arts Ltd., Nairobi, KE, pp. 8-12.

Hecht T. 2000. Considerations on African aquaculture. World Aquac $31,12-19$.

John DM and Lawson GW. 1997. Seaweed biodiversity in West Africa: a criterion for designating marine protected areas. In: The Coastal Zone of West Africa: Problems and Management. Evans SM, Vanderpuye CJ and Armah AK, eds. Penshaw Press, Sunderland, GB, pp. 111-123.

Kaliba AR, Ngugi CC, Mackambo J and Quagrainie KK. 2007. Economic profitability of Nile tilapia (Oreochromis niloticus L.) production in Kenya. Aquac Res 38, 1129-1136. http://dx.doi. org/10.1111/j.1365-2109.2007.01772.x.

Kapinga I. 2012. Characterization of Artemia from solar salt works in Kenya. M.sc. Thesis, Ghent University, Ghent, BE.

Kudhongania AW and Kitamwebwa DBR. 1995. Impact of environmental change, species introductions and ecological interactions on the fish stocks of Lake Victoria. In: The Impact of Species Changes in African Lakes. Pitcher TJ and Hart PJB, eds. Chapman and Hall, London, GB, pp. 19-32.

Lake Victoria Basin Commision. 2011. A Study on Aquatic Biodiversity in the Lake Victoria Basin. ACTS Press, African Centre for Technology Studies, Lake Victoria Bassin Commision, Nairobi, KE.

Liti DM, Mugo RM, Munguti JM and Waidbacher H. 2006. Growth and economic performance of Nile tilapia (Oreochromis niloticus L.) fed on three brans (maize, wheat and rice) in fertilized ponds. Aquac Nutr 12, 239-245. http://dx.doi.org/10.1111/j.13652095.2006.00397.x.

Maar A, Mortimer MAE and Van der Lingen I. 1966. Fish Culture in Central East Africa. FAO, Rome, IT.

Mremi PA. 2011. Pond production of Artemia in a solar salt work in Kenya. M.sc. Thesis, Ghent University, Ghent, BE.

Mucai M, Wangila BC and Norman N. 2011. Factors Determining Structure and Development of Fish Farming among Small Scale Operators in Western Kenya. In: Samaki News: Aquaculture Development in Kenya towards Food Security, Poverty Alleviation and Wealth Creation. Vol. 7. No. 1. pp. 30-45

Munguti J and Charo-Karisa H. 2011. Fish Feeds and Aquaculture Development in Kenya. In: Samaki News: Aquaculture development in Kenya towards food security, poverty alleviation and wealth creation. Vol. 7. No. 1. pp. 27-29.

Munguti J, Charo-Karisa H, Opiyo MA, Ogello EO, Marijani E, Nzayisenga $L$ and Liti D. 2012. Nutritive value and availability of commonly used feed ingredients for farmed Nile Tilapia (Oreochromis niloticus L.) and African catfish (Clarias gariepinus, Burchell) in Kenya, Rwanda and Tanzania. Afr J Food Agric Nutr Dev 12, 1-22

Musa S, Aura MC, Owiti G, Nyonje B, Orina P and Charo-Karisa H. 2012. Fish farming enterprise productivity program (FFEPP) as an impetus to Oreochromis niloticus (L.) farming in Western Kenya: lessons to learn. Afr J Agric Res, 7, 1324-1330. http://dx.doi. org/10.5897/AJAR11.1608.

Ngugi CC and Manyala JO. 2004. Aquaculture extension services in Kenya. In: Aquaculture Extension Services in Sub-Saharan Africa. Fisheries Department Circular No. 1002. Food and Agriculture Organization of the United Nations, ed. FAO Fisheries Department, Rome, IT, pp. 35-42.

Ngugi CC, Bowman JR and Omolo BO. 2007. A New Guide to Fish Farming in Kenya. Aquaculture Collaborative Research Support Program, Naitobi, KE.

Nyonje BM, Charo-Karisa H, Macharia SK and Mbugua M. 2011. Aquaculture Development in Kenya: Status, Potential and Challenges. In Samaki News: Aquaculture Development in Kenya towards Food Security, Poverty Alleviation and Wealth Creation. Vol. 7. No. 1. pp. 8-11.

Obiero KO, Raburu PO, Okeyo-Owuor JB and Raburu EA. 2012. Com- 
Munguti et al. (2014) Development of Aquaculture in Kenya

munity perceptions on the impact of the recession of Lake Victoria waters on Nyando Wetlands. Sci Res Essays 7, 1647-1661.

Ogello EO. 2013. Genetic differentiation of Artemia franciscana (Kellogg, 1906) in Kenyan coastal salt works. M.sc. Thesis, Ghent University, Ghent, BE.

Ogello EO and Opiyo MA. 2011. A Review of the African Catfish Production in Kenya: Opportunities and Challenges. In: Samaki News: Aquaculture Development in Kenya towards Food Security, Poverty Alleviation and Wealth Creation. Vol. 7. No. 1. pp. 18-20.

Ogello EO, Mlingi FT, Nyonje BM, Charo-Karisa H and Munguti JM.

2013. Can integrated livestock-fish culture be a solution to East Africa's food insecurity? A review. Afr J Food Agric Nutr Dev $13,8058-8076$.

Ogutu-Ohwayo R. 2004. Management of the Nile perch, Lates niloticus, fishery in Lake Victoria in light of the changes in its life history characteristics. Afr J Ecol 42, 306-314. http://dx.doi.org/10.1111/ j.1365-2028.2004.00527.x.
Otieno MJ. 2011. Fishery Value Chain Analysis: Background Report Kenya. FAO, Rome, IT, pp. 2-10 .

Rakocy JE. 1989. Tank Culture of Tilapia. Southern Regional Aquaculture Center, L-2409 SRAC Publication No. 282. Texas Agricultural Extension Service, College Station, TX, US.

Shoko AP, Getabu A, Mwayuli G and Mgaya YD. 2011. Growth performance, yields and economic benefits of Nile Tilapia Oreochromis niloticus and Kales Brassica oleracea cultured under vegetablefish culture integration. Tanzan J Sci 37, 37-48. http://dx.doi. org/10.4314\%2Ftjs.v37i1.

Sorgeloos P. 1980. Life history of the brine shrimp Artemia. In: Proceedings of the International Symposium on the Brine Shrimp Artemia salina. Vol. 1. Morphology, Genetics, Radiobiology, Toxicology. Corpus Christi, TX, US, pp. 20-23.

Sorgeloos P, Dehasque M, Dhert P and Lavens P. 1995. Review of some aspects of marine fish larviculture. ICES Mar Sci Symp 201, 138142. 